\title{
EFISIENSI PENGELUARAN PEMERINTAH BIDANG PENDIDIKAN DAN BIDANG KESEHATAN KABUPATEN/KOTA DI KALIMANTAN SELATAN
}

\section{Ecoplan}

Vol. 3 No. 1, April

2020, hlm 34-42

ISSN p: 2620-6102

e: 2615-5575

\author{
Muhamad Rusmin Nuryadin, Dewi Rahayu, Muzdalifah \\ Jurusan Ilmu Ekonomi dan Studi Pembangunan, Universitas Lambung Mangkurat \\ *E-mail corresponding author: dewirahayu@ulm.ac.id
}

Abstract-This study aims to evaluate the efficiency of government expenditures (education and health) in regencies/municipalities of South Kalimantan. The data used is secondary data. This study uses the Data Envelopment Analysis (DEA) to determine the efficiency of government expenditure in regencies/municipalities of South Kalimantan during the period of 2012 2016. The results showed that the efficiency level of government expenditure on education was still low except for Banjarbaru City, Banjarmasin City and Banjar District. These three areas achieved a perfect efficiency. It can be viewed from educational achievements (in this study: Expected Years of Schooling and Mean Years School), and the input of the realization of education expenditure. Similarly, Banjarmasin City and Banjarbaru City can achieve perfectly efficiency of government expenditure on health sector, in terms of life expectancy as output and the realization of expenditure as input. Meanwhile, other regions are still at low level of efficiency.

Keywords: Efficiency, Government Expenditure, Education Spending, Health Spending, Data Envelopment Analysis (DEA)

\section{THE EFFICIENCY OF GOVERMENT EXPENDITURES AND ITS EF- FECT ON ECONOMIC GROWTH IN SOUTH KALIMANTAN}

\begin{abstract}
Abstrak -_Penelitian ini bertujuan untuk mengevaluasi efisiensi pengeluaran pemerintah (bidang pendidikan dan bidang kesehatan) kabupaten/kota di Kalimantan Selatan. Penelitian ini menggunakan data sekunder. Data Envelopment Analysis (DEA) digunakan untuk mengetahui tingkat efisiensi menggunakan dengan sampel meliputi seluruh kabupaten/kota di Kalimantan Selatan selama periode 2012 - 2016. Hasil penelitian menunjukkan bahwa tingkat efisiensi penggunaan pengeluaran pemerintah bidang pendidikan masih rendah kecuali untuk Kota Banjarbaru, Kota Banjarmasin dan Kabupaten Banjar yang mencapai efisiensi sempurna bila dilihat dari output capaian pendidikan (dalam penelitian ini Harapan Lama Sekolah dan Rata-rata Lama Sekolah) dan input realisasi pengeluaran bidang Pendidikan. Begitu pula halnya dengan efisiensi pengeluaran bidang kesehatan bila dilihat dari angka harapan hidup sebagai output dan realisasi pengeluaran bidang kesehatan sebagai input, hanya Kota Banjarmasin dan Kota Banjarbaru yang dapat mencapai efisiensi sempurna, sementara daerah lainnya di Kalimantan Selatan masih berada pada tingkat efisiensi yang rendah.
\end{abstract}

Kata kunci: Efisiensi, Pengeluaran Pemerintah, Belanja Pendidikan, Belanja Kesehatan, Data Envelopment Analysis (DEA)

Jl. H. Hasan Basry No.29, Pangeran, Banjarmasin Utara, Kota Banjarmasin, Kalimantan Selatan E-mail: 


\section{PENDAHULUAN}

Dalam upaya membangun suatu daerah, pemerintah melakukan berbagai program kegiatan yang dapat meningkatkan bukan hanya pertumbuhan ekonomi tetapi juga tingkat kesejahteraan masyarakatnya. Oleh karena itu, pengeluaran pemerintah sangat diperlukan untuk membiayai berbagai program tersebut. Program yang dilaksanakan pemerintah beragam, sementara dana yang dialokasikan jumlahnya terbatas. Agar tujuan pemerintah dalam hal meningkatkan kesejahteraan masyarakat tersebut, tentu saja perlu mengalokasikan dana yang terbatas tersebut secara efisien.

Pengeluaran pemerintah bidang pendidikan dan bidang kesehatan sangat erat kaitannya dengan keberhasilan pembangunan. Adanya kebijakan otonomi daerah yang salah satunya diimplementasikan dengan desentralisasi fiskal. Kebijakan tersebut memberikan kewenangan yang lebih besar kepada pemerintah daerah dan diharapkan mampu mencapai optimalisasi kinerja pemerintahan daerah.

Dengan berlakunya otonomi daerah, pemerintah daerah menjalankan otonomi seluas-luasnya untuk mengatur dan mengurus sendiri urusan pemerintahan berdasarkan asas otonomi dan tugas pembantuan. Oleh karena itu, tugas dan tanggung jawab yang diemban oleh pemerintah daerah dalam melaksanakan pembangunan daerah akan semakin banyak. Termasuk dalam hal pengelolaan anggaran (APBD) yang merupakan salah satu instrumen kebijakan yang dijalankan pemerintah untuk mencapai tujuan pembangunan daerah.

Pengukuran efisiensi pengeluaran pemerintah daerah dalam konteks anggaran berbasis kinerja merupakan sesuatu yang urgent untuk melihat kinerja pemerintah daerah dalam mengalokasikan anggaran sehingga memberikan dampak yang besar bagi peningkatan kesejahteraan masyarakat di daerahnya. Desentralisasi fiskal didesain dengan asumsi bahwa pemerintah daerah lebih mengetahui apa yang dibutuhkan dan memahami dengan baik kondisi daerahnya masing-masing.

Efisiensi dalam pengeluaran pemerintah dapat didefinisikan sebagai suatu kondisi ketika tidak mungkin lagi relokasi sumber daya dilakukan untuk meningkatkan kesejahteraan masyarakat. Dengan kata lain, setiap rupiah yang dibelanjakan oleh pemerintah daerah menghasilkan kesejahteraan masyarakat yang paling optimal. Ketika kondisi tersebut terpenuhi, maka dikatakan pengeluaran pemerintah telah mencapai tingkat yang efisien (Kurnia, 2006).

Beberapa penelitian terdahulu mengenai efisiensi pengeluaran pemerintah di antaranya adalah Kurnia (2006), Pertiwi (2007), dan Indriati (2014). Hasil penelitian Kurnia (2006) tentang pengukuran kinerja dan efisiensi sektor publik menggunakan metode Public Sector Efficiency (PSE) maupun Free Disposable Hull (FDH) di Jawa tengah menunjukkan bahwa belum adanya korelasi antara alokasi pengeluaran pemerintah kabupaten/kota di Jawa Tengah dengan efisiensi penggunaannya. Penelitian dengan lokasi yang sama oleh Pertiwi (2007) dengan menggunakan metode Data
Envelopment Analysis (DEA) memperoleh hasil bahwa pengeluaran pendidikan kabupaten/kota di Jawa Tengah belum mencapai pada tahun 1999-2002, akan tetapi terjadi peningkatan efisiensi di tahun 2002. Hal ini menunjukkan bahwa pemerintah daerah di Jawa Tengah telah melakukan perbaikan kinerja pemerintahan di masing-masing daerahnya, meskipun belum optimal. Hasil penelitian Indriati (2014) di kabupaten Sumbawa menunjukkan bahwa pengeluaran pemerintah di bidang pendidikan dan bidang kesehatan secara rata-rata belum efisien, namun selama periode penelitian untuk efisiensi teknis biaya bidang pendidikan yang konsisten mencapai skor efisiensi maksimum 100 persen adalah Kecamatan Batu Lanteh, sedangkan daerah yang sudah mencapai kondisi efisien dalam teknis sistem adalah Kecamatan Sumbawa, Kecamatan Rhee dan Kecamatan Maronge. Adapun daerah yang mencapai kondisi efisien dalam teknis biaya bidang kesehatan selama periode penelitian secara konsisten adalah Kecamatan Lantung, dalam teknis sistem adalah Kecamatan Maronge, Kecamatan Sumbawa, Kecamatan Utan dan Kecamatan Alas Barat.

Ketidakefisienan yang tinggi pengeluaran publik untuk pendidikan juga ditemukan di Kroasia. Hal ini merupakan temuan Ahec Sonje et al. (2018) yang meneliti efisiensi pengeluaran publik untuk pendidikan menengah dan tersier di negara-negara Anggota Baru (NMS) di UE. Temuan yang berbeda ketika dilihat di negara-negara OECD yang menunjukkan bahwa efisiensi di negara-negara yang dievaluasi relatif tinggi. Temuan ini dikemukakan oleh Gavurova et al. (2017) yang menggunakan Data Envelopment Analysis (DEA), dengan pengeluaran pemerintah berdasarkan data yang diterbitkan oleh Dana Moneter Internasional (IMF) sebagai input dan kualitas pendidikan melalui indikator PISA yang diterbitkan oleh OECD sebagai output.

Menurut Herrera \& Ouedraogo (2018), pemerintah negara-negara berkembang biasanya menghabiskan antara 20 dan 30 persen dari produk domestik bruto. Oleh karena itu, perubahan kecil dalam efisiensi belanja publik dapat berdampak besar pada pertumbuhan produktivitas agregat dan tingkat produk domestik bruto. Oleh karena itu, mengukur efisiensi dan membandingkan kombinasi input-output dari berbagai unit pengambilan keputusan menjadi tantangan utama.

Mengingat bahwa masih rendahnya indeks pendidikan dan kesehatan di Kalimantan Selatan, maka menjadi penting melihat bagaimana efisiensi alokasi pengeluaran pemerintah di kedua bidang tersebut. Studi ini bertujuan menganalisis tingkat efisiensi pengeluaran pemerintah bidang pendidikan dan kesehatan kabupaten/kota di Kalimantan Selatan. Sisa dari makalah ini meliputi metode, hasil dan pembahasan, dan kesimpulan.

\section{METODE PENELITIAN}

Penelitian Herrera \& Pang (2005) mengukur efisiensi pengeluaran pemerintah di sektor kesehatan dan pendidikan di negara-negara berkembang. Mereka 
menggunakan pengeluaran pemerintah per kapita untuk sektor pendidikan dan kesehatan sebagai input. Sementara untuk output mereka menggunakan pendaftaran sekolah dasar (kotor dan bersih), pendaftaran sekolah menengah (kotor dan bersih), melek huruf kaum muda, rata-rata tahun sekolah, tingkat pertama selesai, tingkat kedua selesai, dan skor pembelajaran untuk sektor pendidikan dan harapan hidup saat lahir, imunisasi (DPT dan campak), dan harapan hidup yang disesuaikan dengan disabilitas (DALE) untuk sektor kesehatan.

Dalam penelitian ini data yang digunakan adalah data sekunder, yaitu data yang telah didokumentasikan dan dipublikasikan secara resmi oleh Badan Pusat Statistik (BPS), Badan Perencanaan Pembangunan Nasional dan Daerah, Kementerian Keuangan, Direktorat Jenderal Perimbangan Keuangan (DJPK), dan instansi lain yang terkait.

Hampir sama dengan Herrera \& Pang (2005) input yang dipertimbangkan dalam penelitian ini adalah realisasi anggaran pendidikan per kapita dan realisasi anggaran kesehatan per kapita, sementara output adalah capaian indikator bidang pendidikan (harapan lama sekolah dan rata-rata lama sekolah) dan indikator bidang kesehatan (angka harapan hidup).

Untuk menghitung efisiensi pengeluaran pemerintah terhadap capaian indikator bidang pendidikan dan bidang kesehatan dengan menggunakan Data Envelopment Analysis (DEA). Metode DEA merupakan sebuah pendekatan yang bersifat non para-

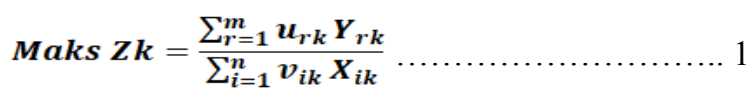

metrik yang didasarkan pada perhitungan Programasi Linear.

Terdapat dua metode utama dalam perhitungan yang dilakukan dengan DEA, yaitu pendekatan secara grafis dan pendekatan programasi linear (Widodo,

$\frac{\sum_{r=1}^{m} u_{r k} Y_{r j}}{\sum_{i=1}^{n} v_{i k} X_{i j}} \leq 1 ; j=1,2, \ldots, n$

2006). Dalam penelitian ini penulis menggunakan pendekatan programasi linear dengan menggunakan software DEAP.

Programasi linear mendefinisikan fungsi tujuan yang akan dipecahkan dengan dibatasi oleh fungsi kendala. Fungsi tujuan adalah rasio total output tertimbang terhadap total input tertimbangnya. Fungsi tujuan dirumuskan dalam Formulasi 1.

Dengan asumsi tidak ada kegiatan ekonomi lain yang memiliki efisiensi yang lebih dari 1 (100\%) apabila dihitung dengan menggunakan bobot tertimbang yang dipilih oleh jenis kegiatan $\mathrm{k}$ di atas, sehingga dapat diformulasikan kembali menjadi Formulasi 2.

Dengan syarat bobot yang dipilih oleh kegiatan ekonomi k tidak boleh bernilai negatif (Widodo, 2006).

\section{HASIL DAN PEMBAHASAN}

Pengeluaran Pemerintah Bidang Pendidikan
Pemerintah selama ini selalu berupaya meningkatkan pertumbuhan ekonomi dan menjaga perekonomian tetap stabil yang pada gilirannya dapat meningkatkan kesejahteraan masyarakat. Salah satu kebijakan yang dilakukan pemerintah adalah kebijakan fiskal yang diwujudkan dengan mengatur pendapatan dan belanja pemerintah. Salah satu belanja pemerintah yang diupayakan untuk meningkatkan kesejahteraan masyarakat adalah pengeluaran di bidang Pendidikan.

Pengeluaran di bidang pendidikan merupakan wujud dari investasi dalam upaya meningkatkan produktivitas sumber daya manusia. Mankiw (2012) menyatakan bahwa seperti halnya sumber daya alam, modal manusia juga merupakan salah satu faktor yang menentukan produksi. Dalam hal ini Mankiw mengartikan modal manusia sebagai perolehan pengetahuan dan keterampilan oleh para pekerja dari pendidikan, pelatihan, dan pengalaman. Jadi dalam hal ini, modal manusia meliputi akumulasi keterampilan dalam program anak usia dini, sekolah dasar, sekolah menengah, perguruan tinggi, dan pelatihan kerja untuk orang dewasa dalam angkatan kerja.

Hal ini sejalan dengan yang dikemukakan Jhingan (2010) yang mengartikan pembentukan modal manusia sebagai suatu proses memperoleh dan meningkatkan keahlian, pendidikan dan pengalaman penduduk yang turut serta dalam menentukan pembangunan ekonomi dan politik suatu negara. Oleh karena itu, pembentukan modal manusia terkait dengan investasi pada manusia dan pengembangannya sebagai suatu sumber yang kreatif dan produktif. Dengan kata lain investasi manusia adalah segala upaya yang dilakukan untuk meningkatkan produktivitas sumber daya manusia yang pada gilirannya turut serta dalam meningkatkan pertumbuhan ekonomi.

Dari berbagai pendapat para ahli mengenai pembentukan modal manusia, maka tidak mengherankan bila pemerintah terus berupaya melakukan perbaikan dalam hal pelayanan di bidang pendidikan, penyediaan infrastruktur pendidikan, dan sistem pendidikan. Pemerintah bahkan menganggarkan pengeluaran di bidang pendidikan duapuluh persen dari APBN.

Realisasi pengeluaran pemerintah di bidang pendidikan di kabupaten/kota yang ada di Provinsi Kalimantan Selatan selama periode 2012-2016 sangat berfluktuasi. Bila dilihat dari rata-rata realisasi pengeluaran bidang pendidikan selama periode 20122016, maka daerah yang mengalokasikan pengeluaran pendidikan terbesar adalah Kota Banjarmasin dengan rata-rata Rp. 519.340 juta per tahun. Hal ini wajar karena Kota Banjarmasin merupakan ibukota Provinsi Kalimantan Selatan dengan jumlah penduduk terbesar, sehingga kebutuhan untuk peningkatan pelayanan pendidikan, pengadaan fasilitas dan infrastruktur pendidikan juga lebih besar. Rata-rata realisasi pengeluaran di bidang pendidikan yang cukup besar juga dialokasikan oleh Kabupaten Banjar dengan pengeluaran sebesar Rp. 416.880 juta per tahun dan Kabupaten Tanah Laut dengan pengeluaran sebesar Rp. 372.401 per tahun. Daerah dengan rata-rata realisasi 
pengeluaran pendidikan terkecil per tahunnya adalah Kota Banjarbaru yaitu sebesar Rp. 229.291 juta.
Pengeluaran bidang pendidikan yang besar tidak menjamin suatu daerah mampu menyediakan pelayanan pendidikan yang lebih baik dibandingkan dengan yang

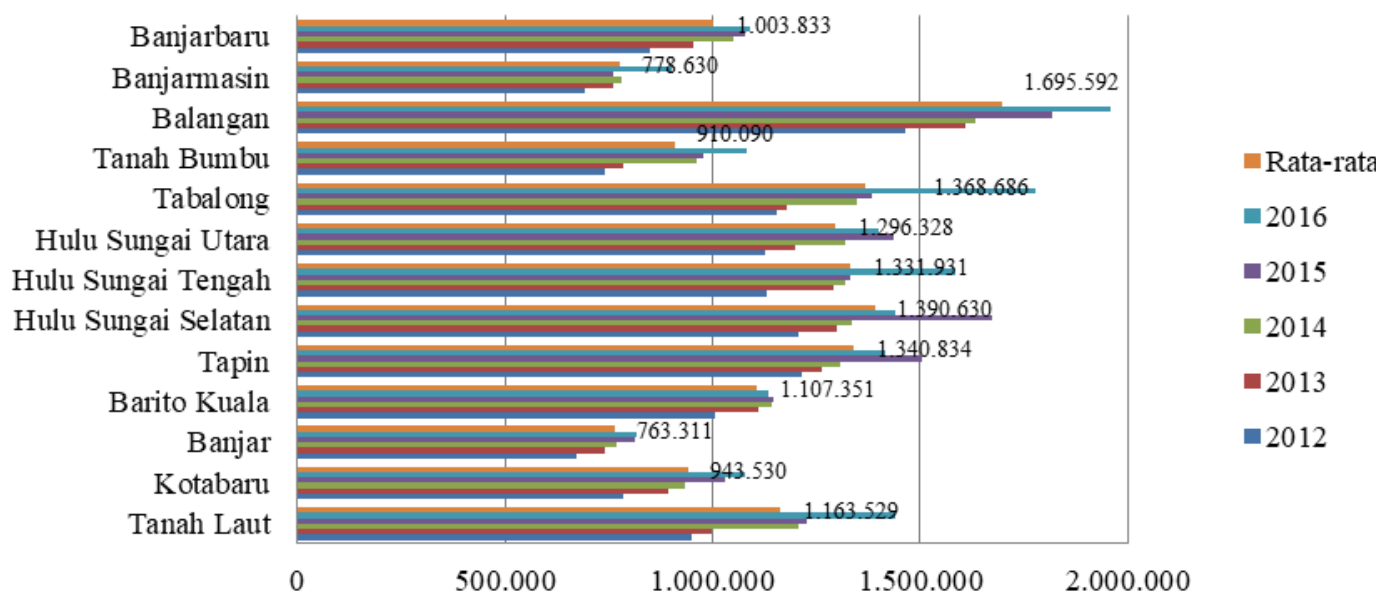

Gambar 1. Realisasi Pengeluaran Bidang Pendidikan Perkapita Menurut Kabupaten/Kota di Kalimantan Selatan Tahun

Catatan: Label pada grafik adalah angka rata-rata

lain. Apalagi bila dihubungkan dengan jumlah penduduk yang membutuhkan pelayanan pendidikan. Bila dihubungkan dengan jumlah penduduk daerah yang memiliki jumlah penduduk besar tentu saja membutuhkan alokasi pengeluaran yang lebih besar pula.

Apabila realisasi pengeluaran pemerintah di bidang pendidikan dirasionalisasikan dengan jumlah penduduk dari masing-masing kabupaten/kota di Kalimantan Selatan, maka daerah yang pengeluaran bidang pendidikan per kapita terbesar selama periode 2012- 2016 secara rata-rata adalah Kabupaten Balangan sebesar Rp. 1.695.592, diikuti oleh Kabupaten Hulu Sungai Selatan Rp. 1.390.630 dan Kabupaten Tabalong sebesar Rp. 1.368.686. Sementara Kota Banjarmasin dengan rata-rata realisasi pengeluaran di bidang pendidikan per kapita sebesar Rp. 778.630 menempati urutan kedua terkecil setelah Kabupaten Banjar dengan rata-rata sebesar Rp. 763.311. Perkembangan realisasi pengeluaran bidang pendidikan per kapita seluruh kabupaten/kota di Kalimantan Selatan dapat dilihat dari grafik pada Gambar 1.

\section{Pengeluaran Pemerintah Bidang Kesehatan}

Pengeluaran pemerintah terkait dengan bidang kesehatan ditujukan untuk memenuhi hak dasar rakyat yaitu hak mendapatkan pelayanan kesehatan. Perbaikan kesehatan masyarakat ditujukan untuk meningkatkan kualitas sumber daya manusia. Pengeluaran pemerintah yang diwujudkan dalam pengeluaran di bidang kesehatan dialokasikan untuk memenuhi salah satu hak dasar untuk memperoleh pelayanan kesehatan. Menurut Todaro \& Smith (2006), fasilitas dan pelayanan kesehatan merupakan prasyarat bagi peningkatan produktivitas masyarakat.

Schultz (1961) menyebutkan bahwa fasilitas dan pelayanan kesehatan, semua pengeluaran yang mempengaruhi kualitas hidup masyarakat yang terkait dengan kesehatan, seperti usia harapan hidup, kekuatan dan stamina, tenaga serta vitalitas merupakan salah satu cara peningkatan kualitas sumber daya manusia. Hal ini sama pentingnya dengan cara lainnya, seperti pelatihan jabatan, pendidikan, program studi lanjutan di luar perusahaan, mapun migrasi.

Realisasi pengeluaran di bidang kesehatan yang dikeluarkan masing-masing pemerintah daerah berbeda-beda. Dilihat dari nilai realisasinya selalu terjadi peningkatan dari tahun ke tahun. Hal ini dilakukan dalam upaya meningkatkan pelayanan kesehatan dan perbaikan kualitas hidup masyarakat. Daerah yang rata-rata pengeluaran bidang kesehatan rata-rata terbesar adalah Kabupaten Banjar, yaitu sebesar Rp. 178.626,20 juta per tahun. Urutan kedua ditempati oleh Kabupaten Hulu Sungai Selatan, yaitu sebesar Rp. 149.932,52 juta per tahun dan diikuti oleh Kabupaten Tanah Laut sebesar Rp. 141.126,20 juta per tahun. Daerah dengan pengeluaran bidang kesehatan paling rendah adalah Kabupaten Balangan dengan rata-rata sebesar Rp. 71.306,55 juta per tahun pada periode yang sama.

Sementara bila dihubungkan dengan jumlah penduduk, Kabupaten Hulu Sungai Selatan dilihat dari rata-rata pengeluaran bidang kesehatan per kapita justru mengalokasikan pengeluaran terbesar dibanding daerah lainnya di Provinsi Kalimantan Selatan, yaitu sebesar Rp. 664.421. Nilai ini lebih besar dibandingkan dengan yang dikeluarkan oleh Kabupaten Banjar. Daerah dengan pengeluaran bidang kesehatan per kapita cukup besar adalah Kabupaten Balangan dengan jumlah Rp. 584.358. Kota Banjarmasin yang memiliki jumlah penduduk terbanyak, sama halnya dengan pengeluaran bidang pendidikan per kapita, mengalokasikan pengeluaran bidang kesehatan per kapita paling kecil, yaitu hanya Rp. 172.246. Perkembangan pengeluaran kesehatan 


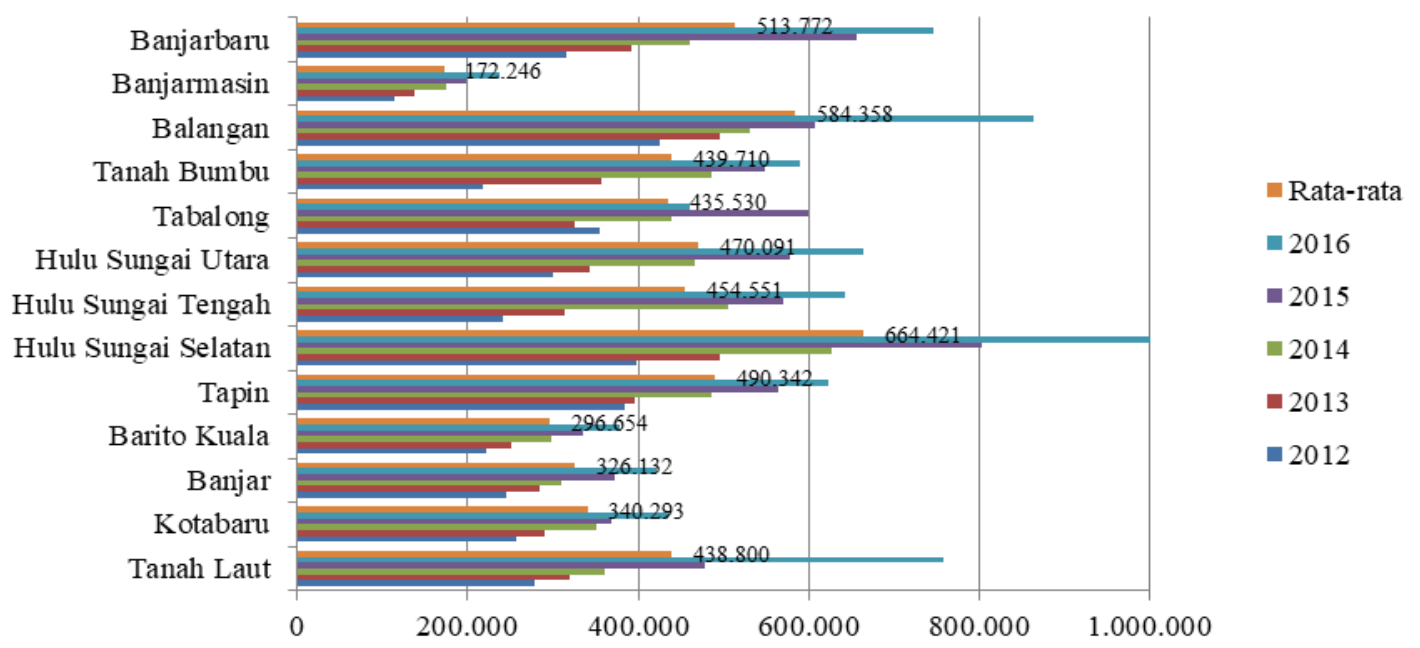

\section{Gambar 2. Realisasi Pengeluaran Bidang Kesehatan Kabupaten/Kota di Kalimantan Selatan Tahun 2012 - 2016 (Dalam} Juta Rupiah)

Catatan: Label pada grafik adalah angka rata-rata

per kapita yang dilakukan pemerintah daerah kabupaten/kota di Kalimantan Selatan melalui APBD dapat dilihat pada Gambar 2.

\section{Indeks Pendidikan}

Salah satu komponen dalam mengukur Indeks Pembangunan Manusia (IPM) adalah tingkat pendidikan yang merupakan dimensi pengetahuan. Sebelumnya dimensi pengetahuan menggunakan gabungan indikator angka melek huruf dan rata-rata lama sekolah, sementara dengan metode baru maka yang menjadi indikator adalah harapan lama sekolah dan rata-rata lama sekolah.

Dilihat dari capaian harapan lama sekolah, perkembangan selama tahun 2012-2016 menunjukkan angka yang semakin meningkat baik untuk Provinsi Kalimantan Selatan maupun kabupaten/kota yang ada di Provinsi Kalimantan Selatan. Angka harapan lama sekolah Provinsi Kalimantan Selatan tahun 2012 adalah 11,54 tahun dan 2016 meningkat menjadi 12,29 tahun atau rata-rata selama periode 2012-2016 adalah 11,93 tahun. Angka ini masih sedikit lebih rendah bila dibandingkan dengan harapan lama sekolah nasional, yaitu 11,68 tahun (2012) dan 12,72 tahun (2016) atau rata-rata 12,29 tahun. Hal ini menunjukkan bahwa harapan lama sekolah Kalimantan Selatan masih di bawah rata-rata nasional.

Di tingkat kabupaten/kota, daerah dengan angka harapan lama sekolah tertinggi adalah Kota Banjarbaru dengan angka 14,55 tahun (2012) dan 14,77 tahun (2016) atau rata-rata selama periode 2012 -2016 adalah 14,69. Sementara Kabupaten Banjar memiliki angka harapan lama sekolah terendah, yaitu 10,57 (2012) dan 11,41 (2016), dimana rata-ratanya hanya mencapai 10,97 tahun. Daerah yang mencapai angka rata-rata harapan lama sekolah lebih tinggi dari Provinsi Kalimantan Selatan hanya Kota Banjarbaru, $(14,69)$ Kota Banjarmasin $(13,61)$ dan Kabupaten

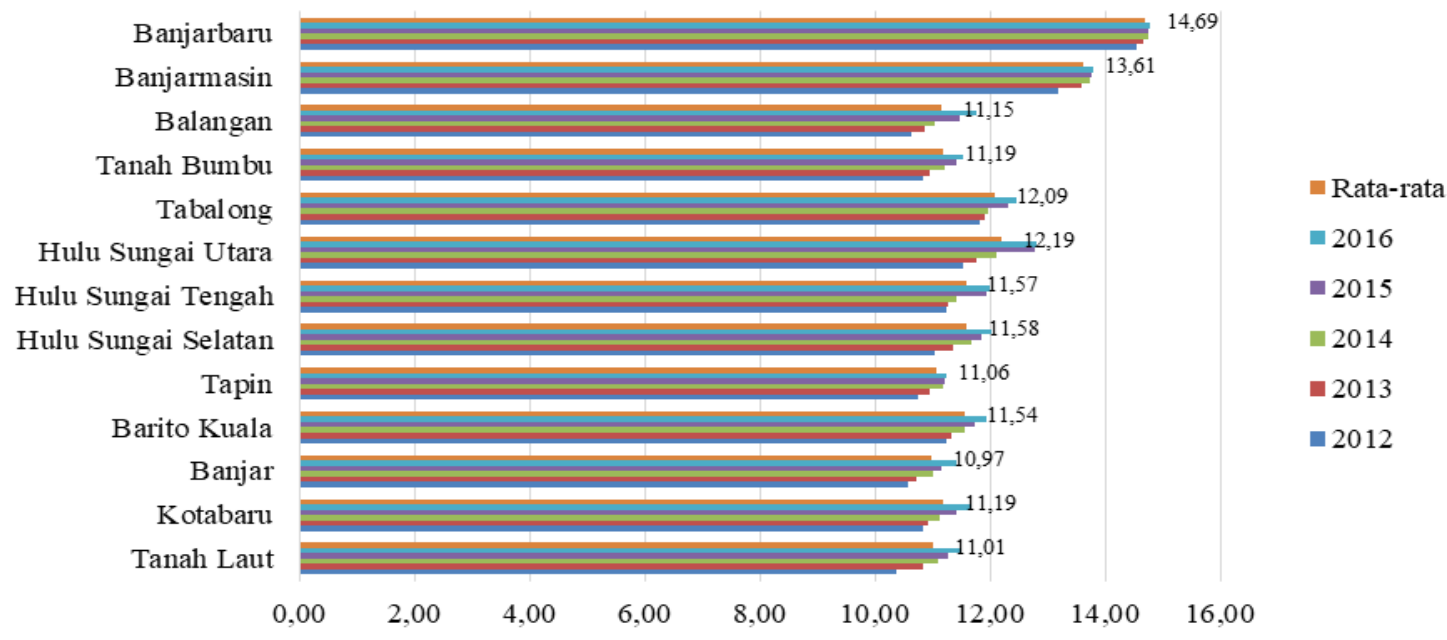

Gambar 3. Harapan Lama Sekolah Menurut Kabupaten/Kota di Kalimantan Selatan Tahun 2012 - 2016 (Dalam Tahun)

Catatan: Label pada grafik adalah angka rata-rata 


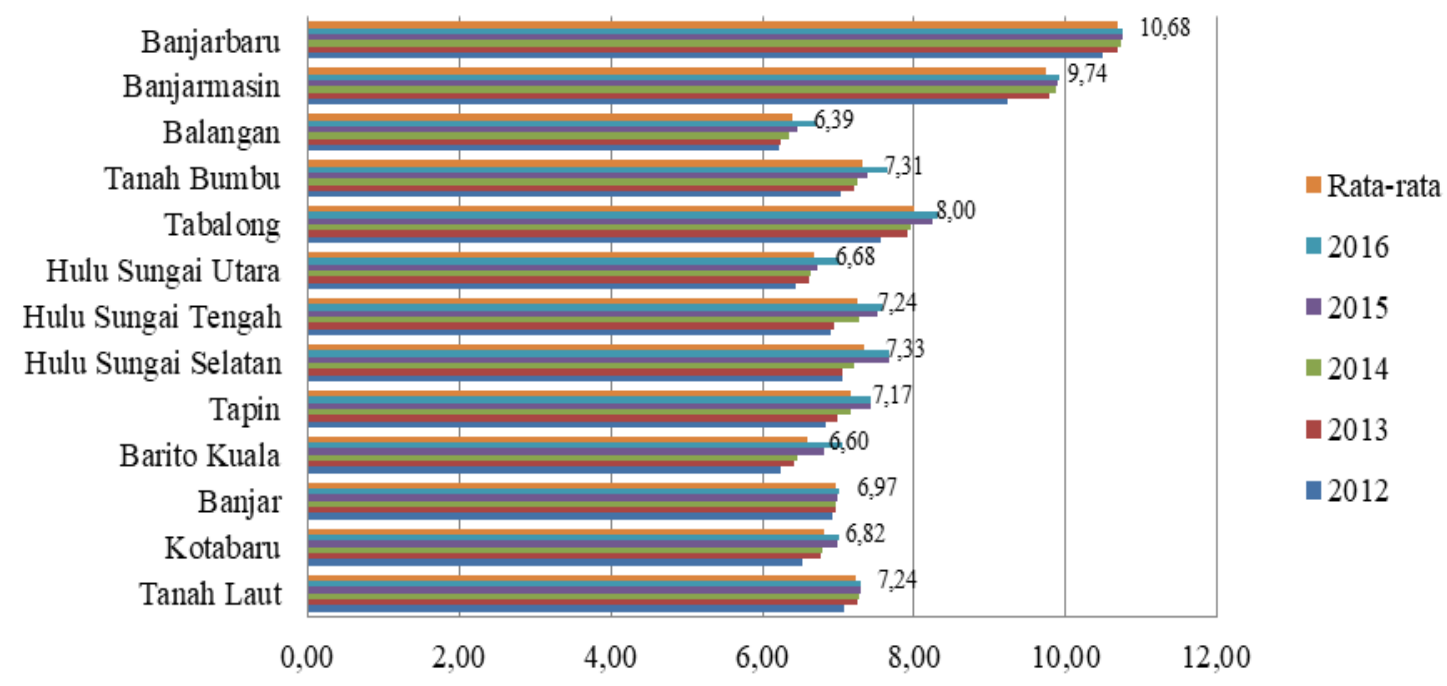

Gambar 4. Rata-Rata Lama Sekolah Menurut Kabupaten/Kota di Kalimantan Selatan Tahun 2012 - 2016 (Dalam Tahun)

Catatan: Label pada grafik adalah angka rata-rata

Sumber: BPS Kalimantan Selatan (https://kalsel.bps.go.id)

Hulu Sungai Utara $(12,19)$ dan Kabupaten Tabalong $(12,09)$. Secara lebih rinci dapat dilihat pada Gambar 3.

Indikator lainnya untuk mengukur dimensi pengetahuan adalah rata-rata lama sekolah. Perkembangan rata-rata lama sekolah juga mengalami peningkatan dari tahun ke tahun baik tingkat kabupaten/ kota maupun di Provinsi Kalimantan Selatan. Angka rata-rata lama sekolah Provinsi Kalimantan Selatan tahun 2012 adalah 7,48 tahun dan pada tahun 2016 meningkat menjadi 7,89 tahun. Angka yang dicapai oleh Provinsi Kalimantan Selatan masih jauh di bawah Indonesia yang mencapai angka 8,42 tahun pada tahun 2016. Lebih rinci rata-rata lama sekolah menurut kabupaten/kota di Kalimantan Selatan disajikan pada Gambar 4.
Gambar 4 menunjukkan angka rata-rata lama sekolah menurut kabupaten/kota di Kalimantan Selatan. Dari tabel tersebut terlihat bahwa pada tahun 2012 tiga urutan terbesar angka rata-rata lama sekolah tertinggi dicapai oleh Kota Banjarbaru (10,48 tahun), Kota Banjarmasin (9,23 tahun) dan Kabupaten Tabalong (7,57 tahun). Urutan tersebut tetap sama pada tahun 2016, yaitu Kota Banjarbaru (10,76 tahun), Kota Banjarmasin (9,91 tahun), dan Kabupaten Tabalong (8,32 tahun). Ketiga daerah dengan angka rata-rata lama sekolah tertinggi, juga menunjukkan capaian di atas angka rata-rata lama sekolah Provinsi Kalimantan Selatan. Daerah dengan angka rata-rata lama sekolah terendah adalah Kabupaten Balangan, yaitu 6,21 tahun (2012) dan 6,71 (2016).

Secara rata-rata selama periode 2012 - 2016

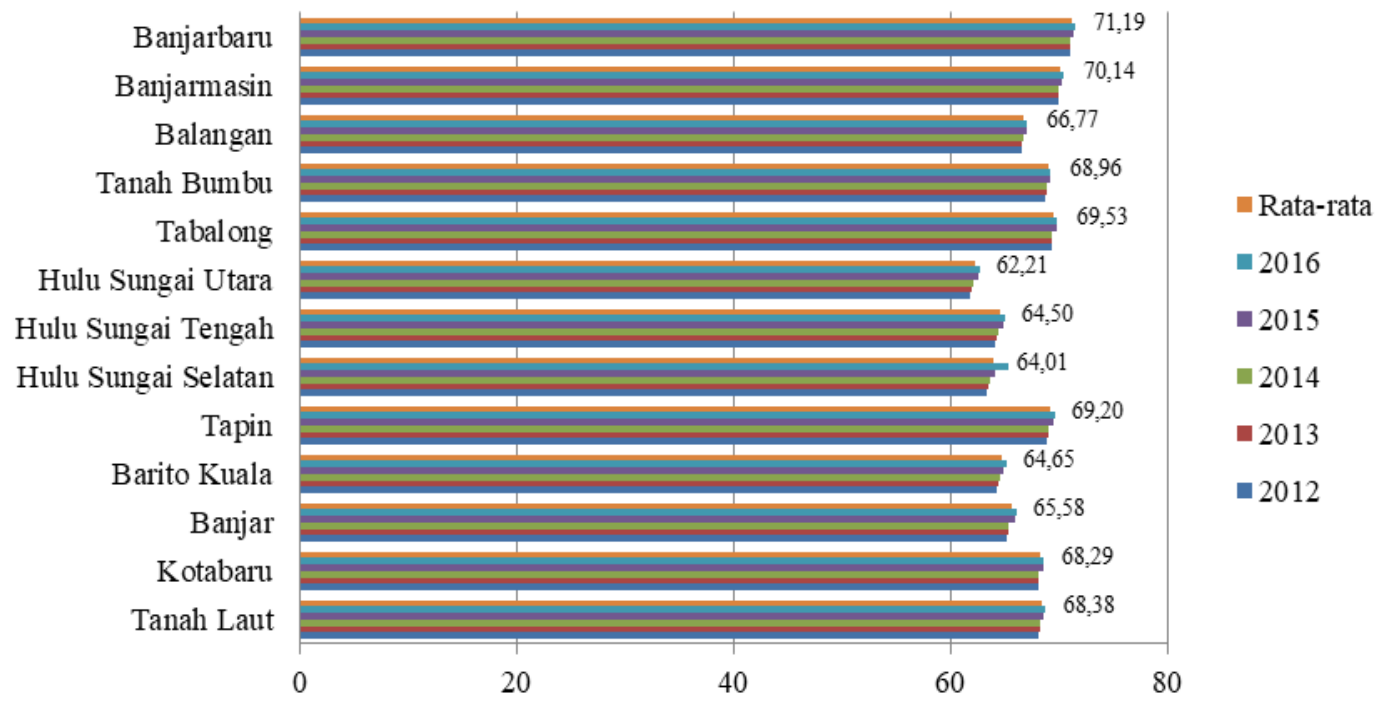

Gambar 5. Angka Harapan Hidup Menurut Kabupaten/Kota di Provinsi Kalimantan Selatan Tahun 2012 - 2016 (Dalam

Catatan: Label pada grafik adalah angka rata-rata

Sumber: BPS Kalimantan Selatan (https://kalsel.bps.go.id) 
rata-rata lama sekolah tertinggi dicapai oleh Kota Banjarbaru dengan rata-rata 10,68 tahun, diikuti oleh Kota Banjarmasin $(9,74)$ dan Kabupaten Tabalong $(8,00)$. Sementara rata-rata angka rata-rata lama sekolah terendah ditempati oleh Kabupaten Balangan $(6,39)$.

Kabupaten Tanah Laut dengan rata-rata angka harapan lama sekolah terendah kedua justru menunjukkan capaian yang cukup baik untuk rata-rata lama sekolah dengan angka rata-rata 7,24. Sebaliknya Kabupaten Hulu Sungai Utara yang berada pada urutan ketiga tertinggi untuk harapan lama sekolah justru menempati urutan ketiga terendah rata-rata lama sekolah $(6,68)$ setelah Kabupaten Balangan $(6,38)$ dan Kabupaten Barito Kuala $(6,60)$.

\section{Angka Harapan Hidup}

Dimensi kesehatan merupakan salah satu ukuran Indeks Pembangunan Manusia (IPM). Dimensi kesehatan diukur dengan angka harapan hidup saat lahir. Selama periode 2012 - 2016 angka harapan hidup Provinsi Kalimantan Selatan sama halnya dengan dimensi pengetahuan menunjukkan angka yang masih di bawah rata-rata nasional. Tahun 2012 angka harapan hidup Provinsi Kalimantan Selatan hanya 67,11 tahun, sedangkan Indonesia sudah mencapai angka 70,20 tahun. Sementara tahun 2016, meskipun menunjukkan peningkatan angka harapan hidup Provinsi Kalimantan Selatan dengan angka 67,92 tahun masih jauh lebih rendah dari Indonesia dengan angka 70,90 tahun. Gambar 5 menunjukkan angka harapan hidup menurut kabupaten/kota di Provinsi Kalimantan Selatan.

Dari Gambar 5 terlihat bahwa selama periode 2012 - 2016 rata-rata angka harapan hidup tertinggi dicapai oleh Kota Banjarbaru dengan angka 71,19 tahun diikuti oleh Kota Banjarmasin 70,14 tahun dan Kabupaten Tabalong 69,53 tahun. Meskipun ketiga daerah tersebut menempati urutan tiga tertinggi angka harapan hidup di Provinsi Kalimantan Selatan, akan tetapi juga masih berada di bawah angka rata-rata nasional yang mencapai angka rata-rata 70,57 tahun di periode yang sama. Daerah dengan angka harapan hidup terendah adalah Kabupaten Hulu Sungai Selatan.

Tabel 1. Efisiensi Pengeluaran Bidang Pendidikan Kabupaten/Kota di Kalimantan Selatan Tahun 2012 - 2016

\begin{tabular}{lcccccc}
\hline \multicolumn{1}{c}{ Kabupaten/Kota } & $\mathbf{2 0 1 2}$ & $\mathbf{2 0 1 3}$ & $\mathbf{2 0 1 4}$ & $\mathbf{2 0 1 5}$ & $\mathbf{2 0 1 6}$ & Rata-rata \\
\hline Tanah Laut & 0,71 & 0,68 & 0,56 & 0,55 & 0,47 & 0,60 \\
Kotabaru & 0,86 & 0,76 & 0,73 & 0,66 & 0,63 & 0,73 \\
Banjar & 1,00 & 0,91 & 0,88 & 0,83 & 0,83 & 0,89 \\
Barito Kuala & 0,67 & 0,61 & 0,60 & 0,60 & 0,60 & 0,62 \\
Tapin & 0,56 & 0,54 & 0,52 & 0,45 & 0,48 & 0,51 \\
Hulu Sungai Selatan & 0,56 & 0,52 & 0,51 & 0,41 & 0,48 & 0,50 \\
Hulu Sungai Tengah & 0,60 & 0,53 & 0,52 & 0,51 & 0,43 & 0,52 \\
Hulu Sungai Utara & 0,60 & 0,57 & 0,52 & 0,48 & 0,49 & 0,53 \\
Tabalong & 0,59 & 0,58 & 0,51 & 0,50 & 0,39 & 0,51 \\
Tanah Bumbu & 0,91 & 0,86 & 0,70 & 0,70 & 0,63 & 0,76 \\
Balangan & 0,46 & 0,42 & 0,41 & 0,38 & 0,35 & 0,40 \\
Banjarmasin & 1,00 & 0,99 & 0,97 & 1,00 & 0,85 & 0,96 \\
Banjarbaru & 1,00 & 1,00 & 1,00 & 0,99 & 1,00 & 1,00 \\
\hline
\end{tabular}

Sumber: Hasil Olah Data Software DEAP, 2019

\section{Efisiensi Pengeluaran Bidang Pendidikan}

Untuk melihat bagaimana efisiensi pengeluaran bidang Pendidikan digunakan software DEAP (Data Envelopment Analysis Program) dengan mengambil model CRS dan VRS standar yang dapat memecahkan perhitungan efisiensi teknis dan skala (Coelli, 1996). Efisien dapat diartikan sebagai kondisi dimana suatu unit pengambil keputusan dapat mencapai tingkat output yang optimum dengan input tertentu atau penggunaan input minimum untuk mencapai tingkat output tententu.

Untuk mengukur tingkat efisiensi pengeluaran bidang Pendidikan dalam penelitian ini, yang dipertimbangkan sebagai input adalah realisasi pengeluaran bidang Pendidikan per kapita (dalam Rupiah) dan sebagai output adalah harapan lama sekolah dan rata-rata lama sekolah (dalam tahun). Decision Making Unit (DMU) dalam penelitian ini adalah pemerintah daerah kabupaten/kota di Provinsi Kalimantan Selatan. Dengan menggunakan software $D E A P$ maka diperoleh tingkat efisiensi pengeluaran bidang pendidikan menurut kabupaten/kota di Provinsi Kalimantan Selatan dapat dilihat pada Tabel 1.

Dari Tabel 1 dapat dilihat bahwa tingkat efisiensi dari tahun ke tahun justru mengalami penurunan. Hal ini mengindikasikan bahwa alokasi pengeluaran bidang Pendidikan masih jauh dari efisien. Meskipun pengeluaran bidang pendidikan terus ditingkatkan akan tetapi capaian terkait bidang 
Tabel 2. Efisiensi Pengeluaran Bidang Kesehatan Kabupaten/Kota di Kalimantan Selatan Tahun 2012 - 2016

\begin{tabular}{lcccccc}
\hline \multicolumn{1}{c}{ Kabupaten/Kota } & $\mathbf{2 0 1 2}$ & $\mathbf{2 0 1 3}$ & $\mathbf{2 0 1 4}$ & $\mathbf{2 0 1 5}$ & $\mathbf{2 0 1 6}$ & Rata-rata \\
\hline Tanah Laut & 0,41 & 0,36 & 0,32 & 0,24 & 0,15 & 0,29 \\
Kotabaru & 0,45 & 0,39 & 0,33 & 0,31 & 0,26 & 0,35 \\
Banjar & 0,47 & 0,40 & 0,37 & 0,31 & 0,27 & 0,36 \\
Barito Kuala & 0,52 & 0,45 & 0,38 & 0,34 & 0,30 & 0,40 \\
Tapin & 0,30 & 0,29 & 0,24 & 0,20 & 0,18 & 0,24 \\
Hulu Sungai Selatan & 0,29 & 0,23 & 0,18 & 0,14 & 0,11 & 0,19 \\
Hulu Sungai Tengah & 0,47 & 0,36 & 0,23 & 0,20 & 0,18 & 0,29 \\
Hulu Sungai Utara & 0,38 & 0,33 & 0,24 & 0,20 & 0,17 & 0,27 \\
Tabalong & 0,32 & 0,35 & 0,26 & 0,19 & 0,25 & 0,27 \\
Tanah Bumbu & 0,52 & 0,32 & 0,24 & 0,21 & 0,19 & 0,30 \\
Balangan & 0,27 & 0,23 & 0,22 & 0,19 & 0,13 & 0,21 \\
Banjarmasin & 1,00 & 0,92 & 0,76 & 0,94 & 0,87 & 0,90 \\
Banjarbaru & 1,00 & 0,83 & 0,71 & 1,00 & 1,00 & 0,91 \\
\hline
\end{tabular}

Sumber: Hasil Olah Data Software DEAP, 2019

pendidikan yang diukur dengan harapan lama sekolah dan rata-rata lama sekolah tidak menunjukkan peningkatan yang signifikan. Dalam analisis efisiensi ini membandingkan rasio antara input dan output, sehingga ketidakefisienan bisa disebabkan output yang dicapai belum optimum dengan tingkat input yang digunakan atau dengan output yang dicapai menggunakan input yang lebih besar daripada yang seharusnya.

\section{Efisiensi Pengeluaran Bidang Kesehatan}

Untuk mengukur tingkat efisiensi pengeluaran bidang kesehatan dalam penelitian ini, yang dipertimbangkan sebagai input adalah realisasi pengeluaran bidang kesehatan per kapita (dalam Rupiah) dan sebagai output adalah angka harapan hidup saat lahir. Decision Making Unit (DMU) dalam penelitian ini adalah pemerintah daerah kabupaten/ kota di Provinsi Kalimantan Selatan. Dengan menggunakan software DEAP maka diperoleh tingkat efisiensi pengeluaran bidang pendidikan menurut kabupaten/kota di Provinsi Kalimantan Selatan dapat dilihat pada Tabel 2.

Dari Tabel 2 dapat dilihat bahwa selama periode 2012 - 2016 hampir semua daerah masih jauh dari efisien, kecuali Kota Banjarmasin pada tahun 2012 dan Kota Banjarbaru pada tahun 2012, 2015 dan 2016. Pada tahun 2013 dan 2014 tidak ada satupun daerah yang mencapai tingkat efisiensi 1 (100\%). Pada tahun 2013 Kota Banjarmasin hanya mencapai tingkat efisiensi 0,92 dan Kota Banjarbaru 0,83. Selanjutnya pada tahun 2014 tingkat efisiensi sangat rendah, yaitu Kota Banjarmasin dan Kota Banjarbaru masing-masing hanya mencapai tingkat efisiensi 0,76 dan 0,71 .

Bila dilihat dari rata-rata tingkat efisiensi selama periode 2012 - 2016, maka rata-rata tingkat efisiensi tiga tertinggi adalah Kota Banjarbaru $(0,91)$ diikuti Kota Banjarmasin $(0,90)$ dan Kabupaten Barito Kuala $(0,40)$. Sementara daerah dengan tingkat efisiensi paling rendah adalah Kabupaten Hulu Sungai Selatan dengan rata-rata 0,19 pada periode yang sama.

\section{KESIMPULAN}

Dilihat dari tingkat efisiensi di mana banyak kabupaten yang belum mengalokasikan pengeluaran bidang pendidikan dan pengeluaran bidang kesehatan, akan tetapi bila dilihat bahwa pengeluaran pemerintah di bidang pendidikan dan kesehatan ini sangat berpengaruh terhadap pertumbuhan ekonomi maka pemerintah daerah tentu saja harus memperhatikan pengalokasian pengeluarannya untuk programprogram yang dapat meningkatkan IPM terkait dengan dimensi pengetahuan dan dimensi kesehatan. Hal ini sangat diperlukan mengingat capaian kedua dimensi tersebut masih berada di bawah angka nasional.

Pengeluaran bidang Pendidikan dan bidang kesehatan yang tinggi tetapi belum mampu memberikan capaian harapan lama sekolah, rata-rata lama sekolah dan angka harapan hidup kabupaten/kota di Provinsi Kalimantan Selatan bisa jadi disebabkan alokasi pengeluaran tersebut lebih banyak digunakan untuk belanja pegawai dan peningkatan kesejahteraan pegawai. Tingkat efisiensi pendidikan yang tinggi hanya dicapai oleh Kota Banjarmasin, Kota Banjarbaru dan Kabupaten Banjar yang merupakan ibukota provinsi dan berada dekat dengan ibukota provinsi yang pada dasarnya memiliki fasilitas pendidikan dan fasilitas layanan kesehatan yang baik dan tersedia dalam jumlah yang cukup. Hal ini ditambah pula dengan investasi yang dilakukan oleh pihak swasta yang tidak tergantung dengan alokasi pengeluaran pemerintah. Dalam penelitian ini masih belum memasukkan bagaimana peran investasi swasta yang umumnya ada di perkotaan dalam hal layanan pendidikan dan layanan kesehatan.

Mengingat capaian bidang Pendidikan (harapan lama sekolah dan rata-rata lama sekolah) dan bidang kesehatan (angka harapan hidup) Provinsi Kalimantan Selatan masih tergolong rendah dibandingkan dengan nasional, maka pemerintah harus berupaya keras untuk meningkatkannya melalui program-program yang dapat meningkatkan layanan pendidikan dan layanan kesehatan terutama di daerahdaerah yang jauh dari ibukota provinsi. Dalam hal ini, perlu perencanaan yang lebih baik dalam mengatur pengalokasian pengeluaran pemerintah kabupaten/ kota dalam bidang pendidikan dan bidang kesehatan 
Nuryadin, M.R., Rahayu, D., Muzdalifah

sehingga dapat mengurangi adanya pemborosan anggaran atau menghindari program yang tidak tepat sasaran. Untuk daerah yang telah mencapai tingkat efisiensi perlu terus dipertahankan bahkan perlu ditingkatkan lagi dalam capaian outputnya, sementara untuk daerah yang belum efisien, perlu perbaikan dalam hal kinerja pemerintahan daerah terutama
SKPD yang terkait langsung dengan bidang pendidikan dan bidang kesehatan sehingga efisiensi dalam pengeluaran pemerintah dapat terealisasi sempurna.

\section{TINJAUAN PUSTAKA}

Ahec Sonje, A., Deskar-Skrbic, M., \& Sonje, V. 